\title{
Does Foreign Direct Investment Boost Innovation? The Case of the Visegrad and Baltic Countries
}

\author{
DOI: 10.12776/QIP.V24I3.1519 \\ Aneta Bobenič Hintošová, Michaela Bruothová, Iveta Vasková
}

Received: 2020-10-11 Accepted: 2020-11-12 Published: 2020-11-30

\begin{abstract}
Purpose: The purpose of the paper is to examine the impact of inward and outward foreign direct investment on innovation performance of the Visegrad and Baltic countries.

Methodology/Approach: The study follows an open-system approach to consider the determinants of national innovation performance, taking into account both inward and outward FDI. We use two-step analysis that combines panel data regression analysis with the design of two FDI - innovation performance matrixes.
\end{abstract}

Findings: The results of the study provide evidence that only outward foreign direct investment of domestic firms contributes significantly to the innovation performance of these countries and that this effect is more visible in the case of the Visegrad countries.

Research Limitation/Implication: The limitations of the study are associated in particular with the selection of SII as a measure of national innovation performance. The use of this indicator is also related to the relatively short period of availability of consistent data, especially in connection with changes in the methodology of SII calculation.

Originality/Value of paper: The policy implications of the paper suggest the need for stronger support of domestic bearers of cross-border capital movements in an attempt to boost national innovation performance.

Category: Research paper

Keywords: innovation performance; inward foreign direct investment; outward foreign direct investment; the Visegrad countries; the Baltic countries 


\section{INTRODUCTION}

There are substantial differences among countries in terms of their innovation performance, which has provoked and stimulated a great academic debate on drivers of countries' innovative progress (e.g. Furman, Porter and Stern, 2002; Krammer, 2009; Carayannis and Grigoroudis, 2014). An important role in this respect is attributed to the flows of foreign direct investment (FDI), especially from an open perspective point of view (e.g. Ramzi and Salah, 2018). It is widely believed that openness to foreign investment promotes the international diffusion of technology (Gong and Keller, 2003). According to the most influential theories of FDI (e.g. Dunning, 1981; Ozawa, 1992) the progression in foreign direct investment flows is closely linked to technological shift and improved innovation capabilities of countries, which leads to the strengthening of their international competitiveness.

Many cross-country empirical studies are dealing with FDI - innovation performance nexus conducted mainly in conditions of developed economies and focusing predominantly on the inward direction of FDI flows. However, not much is known about the effect of investment abroad (e.i. outward FDI) on the innovation performance of the investing country, as it was recently highlighted also by Sarin and Kumar (2019). This is especially the case of developing and transition countries, which are trying to catch up with developed countries in terms of their technological and scientific development. The present research attempts to fill in the outlined gap in the empirical literature by examining the impact of inward as well as outward foreign direct investment on national innovation performance in the case of the Visegrad and Baltic countries. The analysis covers the period from 2009 to 2019 and, from a methodological point of view, combines panel data regression analysis with the design of FDI innovation performance matrixes.

In terms of innovation performance, the Visegrad and Baltic countries belong to the group of moderate innovators compared to the other European Union Member States (EU Member States). One of the positive exceptions in this regard is Estonia, which has seen a positive shift to a group of strong innovators in the last year due to strengthening of its human resources and intellectual assets (European Commission, 2020). Although the other Visegrad and Baltic countries have also made positive changes in their innovation performance, this is still not enough to constantly close the performance gap between them and the highly developed European countries (Kondratiuk-Nierodzińska, 2016). However, the role of foreign direct investment in this context is not clear and is not sufficiently empirically justified. Moreover, there is a large discrepancy between inward and outward FDI, in terms of its evolution over time, volume, nature, and motives. Because the Visegrad and Baltic countries first became prime targets for inward FDI (Gauselmann, Knell and Stephan, 2011) and the increase in the volume of outward FDI is more evident only in recent years, there is little research examining the impact of outward FDI on their innovation performance. 
The rest of the paper is organized as follows: The second part introduces the theoretical background related to the issue with special emphasis on the results of studies conducted within the Visegrad and/or the Baltic countries. The third part explains the objective, methodology, and data used within own research. The fourth part presents the results of panel data regression analysis and construction of two FDI - innovation performance matrixes where the position of the Visegrad and Baltic countries is visible in the broader European context, followed by the discussion of own empirical findings. The fifth part brings concluding remarks with outlined future research directions.

\section{THEORETICAL BACKGROUND}

Countries are increasingly trying to stimulate their innovation activities as a path toward enhanced international competitiveness. This stimulation can be done locally and/or through foreign involvement. As pointed out by Matusik, Heeley and Amorós (2019) stimulation of innovativeness on a local level can include means like investment aid, special projects targeted at innovation knowledge sharing among home country firms, or another kind of supports, e.g. tax allowances. On the other hand, countries may also attract foreign investors especially through the favorable business environment as well as various foreign investment promotion tools. There is a rich literature on direct and spillover effects associated with FDI, however, our focus is on studies examining the impact of FDI on innovation performance at a more aggregated level.

One of the first studies to examine the impact of foreign direct investment flows on the technology diffusion was a study by Borensztein, De Gregorio and Lee (1998), which utilized data on FDI flow from industrialized countries to 69 developing countries. Based on the results, FDI can be considered as an important means of technology transfer, which contributes to growth relatively more than domestic investment.

Subsequently, many studies appeared, which in most cases proved a positive impact of inward FDI on the innovation performance of the host country (e.g. Blind and Jungmittag, 2004; Gorodnichenko, Svejnar and Terrell, 2010; Ghazal and Zulkhibri, 2015; Arun and Yildrim, 2017; Wu, Ma and Zhuo, 2017; Li, Lee and Park, 2020). The most common reasons for this finding lie in direct increase of innovation output through innovations of foreign-owned firms and in indirect spillovers effecting domestic firms through supply chain technology transfer. However, there are also some studies proving in some situations insignificant (Qu et al., 2013; Arun and Yildrim, 2017) or negative effects (e.g. Fu, Pietrobelli and Soete, 2011; Filippetti, Frenz and Ietto-Gillies, 2017; Song and Zhang, 2017), especially in the case of countries with low absorptive capacity, where inward FDI could crowd out local innovation activities and restrain further development of related local knowledge. 
With regard to the impact of outward FDI on the innovation performance, the empirical evidence is not so rich, mostly showing the positive impact of outward FDI on the innovation level of the host country (e.g. Pradhan and Singh, 2009; Li et al., 2016; Filippetti, Frenz and Ietto-Gillies, 2017; Li, Lee and Park, 2020). A common explanation for this is connected with the learning process, i.e. knowledge transfers from local firms in the host country.

However, only a limited number of studies dealing with similar issues have been conducted in conditions of the Visegrad and Baltic countries. Fifeková and Nemcová (2015) studied among others also the impact of inward FDI on innovation-related performance growth in conditions of the Visegrad countries. They concluded that the presence of foreign investors in these countries not only contributed to technology transfer, but also brought intangible assets such as marketing and management skills, knowledge capital and innovation skills. However, the extent to which inward FDI positively affects the innovation-led growth of the Visegrad countries depends predominantly on the formation of the economic environment that is capable to absorb positive effects brought by inward FDI and to foster them further.

A contradictory effect of inward FDI on the national innovative capacity was detected by Andrijauskiene and Dumciuviene (2019) within their investigation of 28 EU Member States. They found that inward FDI supports a country's national innovative capacity by encouraging the employment in knowledge-intensive sectors and having a positive effect on trademark and design applications, while no significant effect on patents was shown. On the other hand, no relationship between marketing and organization innovation as non-technological innovation output and inward FDI was detected.

To sum up, there is no empirical consensus on the FDI flows - national innovation performance nexus. At the same time, according to the best knowledge of the authors, there is no study that would compare specifically a group of the Visegrad and Baltic countries in this regard, while paying attention also to the outward FDI. Hence, the results of the study can enrich the existing literature in this field.

\section{METHODOLOGY}

The research is based on the assumption, that foreign direct investment flows affect national innovation performance, but the strength and direction of dependence appear to be country-specific (Arun and Yildrim, 2017; Wu, Ma and Zhuo, 2017). Hence, the objective of the present paper is to identify the impact of inward and outward foreign direct investment on national innovation performance in conditions of the Visegrad and Baltic countries.

The key variable we focus on in our research is innovation performance at the country level. To ensure the comparability of the data and to assess innovation performance in its complexity, the composite indicator, namely Summary 
Innovation Index (SII) introduced by the European Commission, is used. Despite some critiques of this indicator in the existing literature (see e.g. Edquist et al., 2018; Švandová and Jirásek, 2019), it is a commonly used indicator of innovation performance within empirical literature (e.g. Albulescu and Drăghici, 2016; Janoskova and Kral, 2019). The SII provides a comparative assessment of the research and innovation performance of the EU Member States and selected third countries. The measurement framework previously distinguished among three main types of indicators and eight innovation dimensions, capturing a total of 25 different indicators. However, the methodology for calculation of SII was significantly modified in 2017 and SII currently consists of a total of 27 different indicators. At the same time, the European Commission (2018) in the European Innovation Scoreboard notes that the results for previous years are not comparable to those reported for 2017 and later. For this reason, our analysis of the impact of FDI flows on innovation performance was divided into two main periods and steps, i.e. before and after revision of the methodology of SII calculation, using different analytical approaches, namely:

In the first step, in line with previous studies addressing similar issues (e.g. Qu et al., 2013; Arun and Yildirim, 2017; Andrijauskiene and Dumčiuvienė, 2019), the regression analysis using panel data was performed with SII as a key dependent variable, for the period 2009 to 2016. As key independent variables, we used the volume of FDI inflows (IFDI) and outflows (OFDI), values of which were taken from the UNCTADSTAT (2020). As additional independent variables within our models, we used indicator of gross domestic product per capita $(G D P)$, inflation rate measured by the harmonized index of consumer prices (IR) and unemployment rates $(U R)$. All the values were taken from Eurostat. In accordance with other similar works (e.g. Wu, Ma and Zhuo, 2017) we added a one-year lag in our analysis to consider the delay in the innovation performance induced by foreign direct investment flows and other variables. Since we operate with panel data, we used the following general panel regression model (1):

$$
Y_{i t}=\beta_{0}+\sum_{k=1}^{K} X_{i(t-1) k} \beta+\varepsilon_{i(t-1)}, t=1,2, \ldots, T, i=1,2, \ldots, N
$$

where, $\beta_{0}$ is a constant, $X_{i(t-1) k}$ represents the $k^{\text {th }}$ explanatory variable of the $(t-1)^{\text {th }}$ year in the country $i, \varepsilon_{\mathrm{i}(t-1)}$ is the error term. $K$ is the number of explanatory variables excluding the constant, $N$ represents the number of countries, $T$ is the time period. Concerning countries included in the analysis, three regression models were run, namely Model (1a) covered all Visegrad and Baltic countries, Model (1b) included only the Visegrad countries (i.e. Czechia, Hungary, Poland and Slovakia) and Model (1c) included only the Baltic countries (i.e. Estonia, Latvia and Lithuania).

We estimated the coefficients of the models with use of a pooled OLS method, or the panel data estimations - fixed-effect or random-effect estimation methods. The appropriate estimation method was selected according to several tests, 
namely F-test for testing, whether there exist panel effects in the model; the Breusch - Pagan Lagrange multiplier test (LM-test) for testing significance of difference across units; and finally the Hausman test for selection between the random- and fixed-effect methods.

In the second step, our ambition was to include the latest available data in the analysis and to evaluate the position of the Visegrad and Baltic countries in the broader context. Based on this, we used a similar approach as in other studies (e.g. Remeikiene et al., 2020) and compiled two FDI - innovation performance matrixes. To capture the longer trend in the development of variables and to follow the one-year lag applied in the first step, the average values of the variables over a three-year period were used, namely: in the case of SII, average values calculated by modified methodology for 2017-2019 were used; in the case of FDI inflows and outflows, average FDI performance indexes for 2016-2018 were calculated, in accordance with following methodological approach:

The relative success of a particular country in attracting FDI can be measured through the inward FDI performance index (IFDIPI) developed by UNCTAD (2002). Later, the outward FDI performance index (OFDIPI) was introduced (UNCTAD, 2004) as a measure of ownership advantage of the firms based in a particular country. Some further empirical studies (e.g. Rodríguez, Gómez and Ferreiro, 2009; Lei et al., 2013) also applied these indexes to evaluate advantages connected with FDI flows. Both indexes, depending on the direction of FDI flows, relate inward (outward) FDI to the economic size of the particular country measured by GDP. They are calculated (Eq. (2)) as the ratio of a country's share in global FDI to its share in global GDP as follows:

$$
\operatorname{IFDIPIi}(\text { OFDIPIi })=\frac{\operatorname{IFDIi}(\text { OFDIi }) / I F D I w(O F D I w)}{G D P i / G D P w}
$$

where, $I F D I P I_{i}-$ the inward FDI performance index of the $i^{\text {th }}$ country, $O F D I P I_{i}-$ the outward FDI performance index of the $i^{\text {th }}$ country, $I F D I_{i}-$ inward FDI of the $i^{\text {th }}$ country, $O F D I_{i}-$ outward FDI of the $i^{\text {th }}$ country, $I F D I_{w}-$ world inward FDI, $O F D I_{w}-$ world outward FDI, GDP - GDP of the $i^{\text {th }}$ country, and $G D P_{w}-$ world GDP.

Values above one indicate that the country receives (or allocates abroad) a higher portion of FDI than its relative economic size. Values below one indicate that the country receives (or allocates abroad) a lower portion of FDI than its relative economic size. The data for calculation of FDI performance indexes were taken from the UNCTADSTAT (2020).

In the two matrixes that put into relation inward/outward FDI performance index and the innovation performance measured through the SII the positions of the EU Member States (including the United Kingdom as the EU member at the time to which the data refer), are recorded. The classification of countries into particular quadrants was performed based on critical values of individual indexes as 
follows: in the case of both FDI performance indexes the critical value refers to one; in the case of SII, the critical value refers to the average value of the index of EU Member States.

\section{RESULTS AND DISCUSSION}

In the first step of our analysis, the impact of inward and outward FDI as well as other variables on the innovation performance of the Visegrad and Baltic countries was examined. Results of the panel data regression with use of appropriate estimation technique selected according to several tests, i.e. randomeffect regression for all countries (Model 1a); fixed-effect regression for the Visegrad countries (Model 1b) and fixed-effect regression for the Baltic countries (Model 1c), are reported in Table 1.

Table 1 - Panel Estimation - Dependent Variable SII

\begin{tabular}{|l|c|c|c|}
\hline & $\begin{array}{c}\text { Model la } \\
\text { RE, all countries }\end{array}$ & $\begin{array}{c}\text { Model lb } \\
\text { FE, Visegrad countries }\end{array}$ & $\begin{array}{c}\text { Model lc } \\
\text { FE, Baltic countries }\end{array}$ \\
\hline Constant & $0.012(0.384)$ & $0.024^{* *}(0.015)$ & $11.879^{*}(6.721)$ \\
\hline IFDI & $0.025(0.041)$ & $0.036(0.031)$ & $0.054(0.146)$ \\
\hline OFDI & $0.043^{*}(0.022)$ & $0.047^{*}(0.018)$ & $0.013(0.122)$ \\
\hline GDP & $-0.271(0.182)$ & $0.071(0.372)$ & $16.32 *(7.841)$ \\
\hline IR & $0.073(0.061)$ & $-0.016(0.043)$ & $-0.085(0.143)$ \\
\hline UR & $-0.054(0.083)$ & $0.113(0.111)$ & $0.208(0.134)$ \\
\hline$R^{2}$ & 0.352 & & 0.931 \\
\hline Adjusted $R^{2}$ & 0.291 & & 0.357 \\
\hline LSDV $R^{2}$ & & 0.971 & \\
\hline Within $R^{2}$ & & 0.385 & \\
\hline
\end{tabular}

Notes: Standard errors are in parentheses. The asterisks denote the statistical significance of coefficients at a level of $10 \%(*), 5 \%(* *)$, and $1 \%(* * *)$, based on p-values.

For all models, the errors are normally distributed, based on the Chi-square test. Since the tests revealed possible heteroscedasticity and serial correlation in errors, the Arellano estimator (suitable in the case of heteroscedasticity and serial/cross-sectional correlation) was used for computation of coefficients in all models.

Based on the results of Model 1, only the independent variable - the outward FDI is a statistically significant determinant of the innovation performance in the Visegrad and Baltic region. In the case of results for the Visegrad countries (Model 1b), with the exception of the constant, only outward FDI significantly affects the innovation performance of these countries. Surprisingly, this is not the 
case of the Baltic countries (Model 1c), where international capital flows seem not to affect significantly the innovation. The results rather indicate that domestic activities and size of the economy (proved by the positive significant impact of GDP) are more important drivers of national innovativeness.

Within the second step of our analysis, the relationship between foreign direct investment flows and innovation performance was conducted on a basis of FDI performance matrix, where the positions of the EU Member States (including the United Kingdom as the EU member at the time to which the data refer) are reported. Two matrixes are designed to put into relation the Summary Innovation Index and inward/outward FDI performance index separately. To capture the longer trend in the development of these indexes, average values over a threeyear period were used, with a one-year lag in the case of FDI performance indexes. The division of countries into individual quadrants was carried out on the basis of critical values as follows: for both FDI performance indexes, the critical value refers to one; in the case of SII, the critical value refers to the average innovation performance of the EU Member States.

Figure 1 shows the position of the EU Member States in terms of their innovation performance in relation to the performance of inward foreign direct investment that the countries received. Cyprus and Malta are not included in the matrix due to the extremely high positive values of the inward FDI performance index.

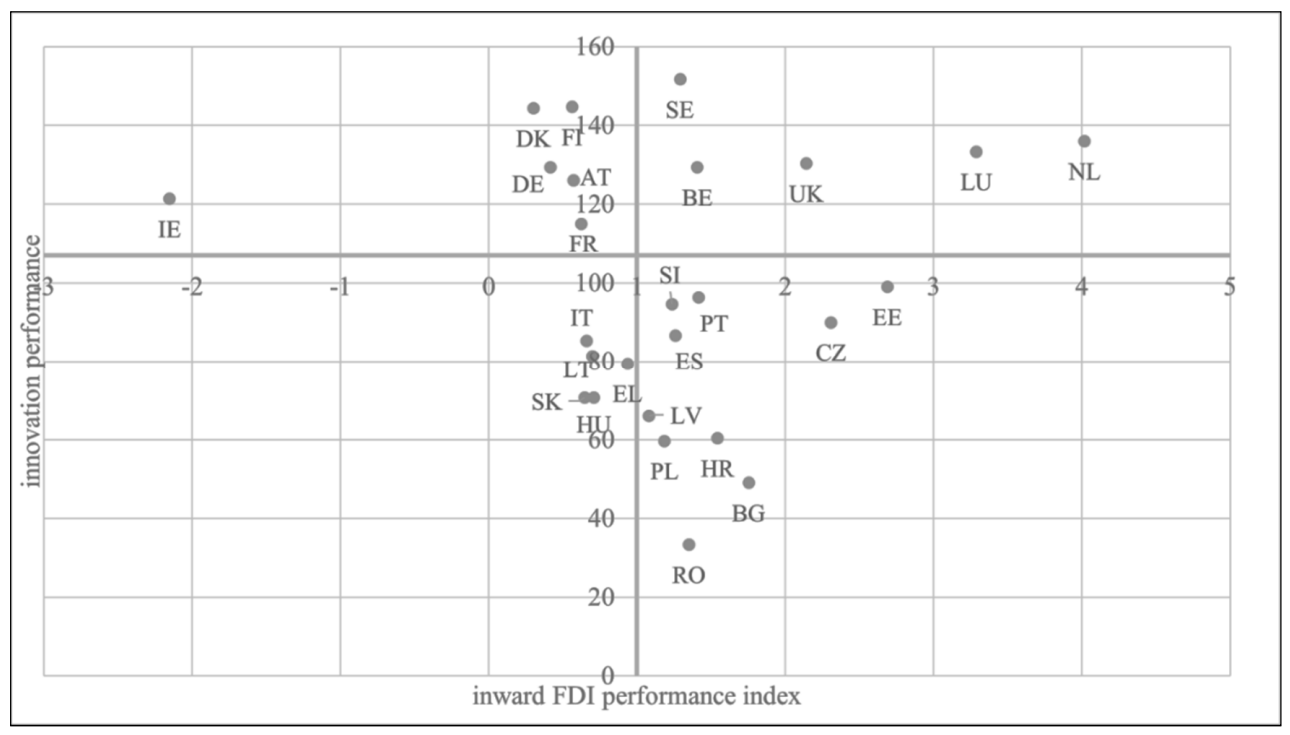

Figure 1 - Inward FDI - Innovation Performance Matrix

Overall, based on the positions of the countries in the matrix, the existence of neither a linear nor a non-linear relationship between the inward FDI performance index and SII is confirmed. At the same time, the Visegrad and Baltic countries cannot be considered as separate and homogenous groups of countries in this regard. Although both groups of countries show below-average 
innovation performance compared to the EU average, their inward FDI performance is different. The worst positions are occupied by Slovakia and Hungary, followed by Lithuania, which countries attract relatively less inward FDI when compared to their economic size. On the other hand, Poland and Latvia attract the volume of inward FDI slightly outweighing their economic size. This positive ratio, however, does not result in superior innovation performance. The best positions from the inward FDI performance index as well as SII point of view are detected by the Czech Republic and Estonia. Especially, in the case of Estonia, the relatively high inward FDI performance is associated with the higher innovation performance that in the last observed year, i.e. 2019 moved Estonia to the group of strong innovators (European Commission, 2020). The heterogeneities identified among the Baltic as well as the Visegrad countries in terms of inward FDI - innovation performance relationship, call for further single country studies in this regard.

Figure 2 shows the position of the EU Member States in terms of their innovation performance in relation to the performance of outward foreign direct investment, i.e. volume of investment that the countries allocated abroad. Luxembourg and Malta are not included in the matrix due to the extremely high values of the outward FDI performance index.

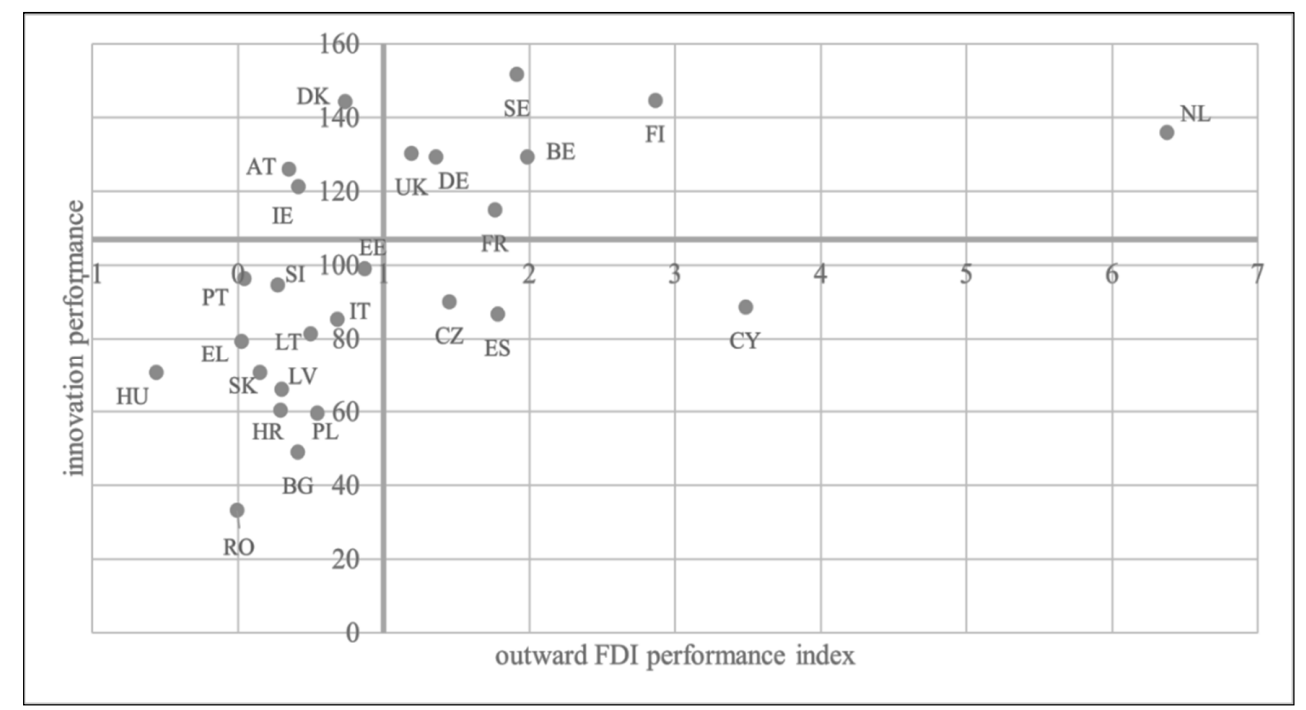

Figure 2 - Outward FDI - Innovation Performance Matrix

Overall, the positions of the countries in the matrix to some extent confirm the results of our previous panel regression, which showed a significant positive relationship between outward FDI and innovation performance; however, this relation appears to be rather non-linear. The majority of countries of our interest lie in the quadrant below the EU average SII and outward FDI performance index below 1. However, there is an obvious trend of increased outward FDI performance index being associated with higher innovation performance. This is 
particularly the case of Estonia, where local companies as bearers of international capital movement, have also potentially contributed to the shift of the country toward strong European innovators in recent year. An exception from this group is the Czech Republic, which achieved the highest outward FDI performance. Thus, it seems that local companies with strong ownership advantages being able to allocate their investments abroad contribute to the highest innovation performance of the country among the Visegrad countries.

Despite expected, theoretically, and empirically underpinned assumptions about the positive impact of inward FDI on innovation performance, this was not proven either in the conditions of the Visegrad nor the Baltic countries. The possible reasons can be found in the nature of inward FDI targeted to the manufacturing industry due to the tendency of the old EU Member States to relocate part of their manufacturing activities there (Fifeková and Nemcová, 2015). Another important reason is generally connected with insufficient absorptive capacity of host countries, as it has already been noticed e.g. by Filippetti, Frenz and Ietto-Gillies (2017). According to Sultana and Turkina (2020) the country can benefit from inward FDI only through a better understanding of absorptive capacity and the transformation of its related factors. Concerning the policy implications, our findings suggest targeting efforts on the development of the absorptive capacity of the home economy, especially the human resource-related component, as a prerequisite for the ability to absorb new external technologies and knowledge. Dimensions connected with human resources and innovators are among the most frequently mentioned weaknesses of the innovation performance of the Visegrad and Baltic countries (European Commission, 2020). The necessity to focus more intensively on human capital accumulation in terms of generating positive effects of inward FDI on innovation in the host country has been highlighted also by other studies (e.g. Konstandina and Gachino, 2020).

On the other hand, our research provides some evidence that outward FDI of domestic firms contributes significantly to the innovation performance of the analyzed countries and that this effect is more visible in the case of the Visegrad countries. These results are to some extent similar to those presented by Filippeti, Frenz and Ietto-Gillies (2017) who found that outward FDI is positively associated with patenting. However, we cannot confirm that outward FDI directly influences patenting activities within the home country, since the SII used as a measure of innovation performance is a composite indicator that mixes input and output innovation indicators and calculates an average of them (Edquist et al., 2018). On the other hand, the innovativeness of the Baltic countries seems to be significantly influenced by factors other than outward FDI, such as the volume of gross domestic product. The factors determining national innovation performance are therefore rather country-specific, probably due to the existence of borders and administrative divisions, which could have a considerable impact on economic conditions (Urbančíková and Zgodavová, 2019). 
So, in the case of the Visegrad countries, domestic firms as drivers of international capital movement, seem to utilize their ownership advantages at the foreign market or/and learn from innovation-advanced host countries, and thus potentially create significant positive synergy effects on the home country's innovation performance. In this context, focus on the idea management system as a potential driver of innovation may be important (Santos et al., 2018). Policymakers should also focus more on implementing policies that support local innovativeness and strengthen it through international capital links with innovative host economies and their firms.

Hence, we can agree with Li, Lee and Park (2020), and this also seems to be the case of the Visegrad and Baltic countries that inward FDI does not induce a substantial knowledge and technology transfer from the home country to the host country due to efforts by foreign multinationals not to disseminate their technologies to the host country but rather to foster their technologies by taking advantage of the competitive advantages of the host country. On the other hand, outward FDI can evoke positive and significant effects from the host country to the home country as a result of acquiring a foreign technology base. From the policy implication point of view, it seems that governments of the Visegrad and Baltic countries should encourage outward FDI to promote domestic innovativeness.

\section{CONCLUSION}

In the presented research we have primarily tested whether foreign direct investment flows boost innovation performance, as measured by the Summary Innovation Index, in the case of the Visegrad and Baltic countries. Our study followed an open-system approach to consider the determinants of national innovation performance, taking into account both inward and outward FDI. We used a two-step analysis that combined panel data regression analysis with the design of two FDI - innovation performance matrixes.

Based on the values of the Summary Innovation Index, the Visegrad as well as the Baltic countries belong to the group of moderate innovators, except Estonia in the recent year, with the innovation performance below the EU average. The overall results of our study suggest a positive and significant impact of outward FDI, i.e. capital investments of domestic firms allocated abroad, on boosting national innovation performance. These outward investors are most likely able to exploit their innovation base through foreign presence and technology transfer. However, even though outward foreign direct investment appears to be a common driving force of the innovation performance of these countries, we found certain differences in the drivers of national innovation performance between the analyzed groups of countries.

In the case of the Visegrad countries, we found that not foreign investors allocating their capital investments in these countries but rather strong domestic 
firms as bearers of outward foreign direct investment are positively influencing national innovation performance. On the other hand, this does not apply to the group of the Baltic countries, where rather other factors, such as the volume of gross domestic product, significantly contribute to innovation performance. Based on these results it seems that factors determining national innovation performance are country-specific.

Our study suffers from certain limitations associated in particular with the selection of SII as a measure of national innovation performance. The use of other indicators could probably lead to slightly different results. The usage of this indicator is also connected with a relatively short period of availability of consistent data, especially concerning changes in the methodology of SII calculation. Future research should therefore also focus on the use of other national innovation performance indicators or combinations thereof.

Since the results indicate some differences between the Visegrad and Baltic countries in terms of significant drivers of national innovation performance, further single-country studies would shed more light on this issue. Another interesting future research direction stems from differences in the motives of foreign direct investment. It is reasonable to predict that strategic assets-seeking outward FDI contributes differently to the innovation performance compared e.g. to resource-seeking outward FDI. Our research suggests the need to focus in more detail on outward investment activities, especially in the case of the Visegrad countries, as these investments will play a potentially crucial role in the innovative development of these countries.

\section{REFERENCES}

Albulescu, C.T. and Drăghici, A., 2016. Entrepreneurial activity and national innovative capacity in selected European countries. The International Journal of Entrepreneurship and Innovation [e-journal], 17(3), pp.155-172. doi: 10.1177/1465750316655902.

Andrijauskiene, M. and Dumčiuvienè, D., 2019. Inward Foreign Direct Investment and National Innovative Capacity. Engineering Economics [ejournal], 30(3), pp.339-348. doi: 10.5755/j01.ee.30.3.22832.

Arun, K. and Yildırım, D.C., 2017. Effects of foreign direct investment on intellectual property, patents and R\&D. Queen Mary Journal of Intellectual Property [e-journal], 7(2), pp.226-241. doi: 10.4337/qmjip.2017.02.05.

Blind, K. and Jungmittag, A., 2004. Foreign Direct Investment, Imports and Innovations in the Service Industry. Review of Industrial Organization [ejournal], 25(2), pp.205-227. doi: 10.1007/s11151-004-3537-x.

Borensztein, E., De Gregorio, J.D. and Lee, J., 1998. How does foreign direct investment affect economic growth? Journal of International Economics [ejournal], 45(1), pp.115-135. doi: 10.1016/s0022-1996(97)00033-0. 
Carayannis, E. and Grigoroudis, E., 2014. Linking innovation, productivity, and competitiveness: Implications for policy and practice. The Journal of Technology Transfer [e-journal], 39(2), pp.199-218. doi: 10.1007/s10961-012-9295-2.

Dunning, J.H., 1981. International production and the multinational enterprise. London: Allen \& Unwin.

Edquist, C., Zabala-Iturriagagoitia, J.M., Barbero, J. and Zofío, J.L., 2018. On the meaning of innovation performance: Is the synthetic indicator of the Innovation Union Scoreboard flawed? Research Evaluation [e-journal], 27(3), pp.196-211. doi: 10.1093/reseval/rvy011.

European Commission, 2018. European Innovation Scoreboard 2018. Luxembourg: Publications Office of the European Union.

European Commission, 2020. European Innovation Scoreboard 2020. Luxembourg: Publications Office of the European Union.

Fifeková, E. and Nemcová, E., 2015. Impact of FDI on Economic Growth: Evidence from V4 Countries. Periodica Polytechnica Social and Management Sciences[e-journal], 23(1), pp.7-14. doi: 10.3311/ppso.7993.

Filippetti, A., Frenz, M. and Ietto-Gillies, G., 2017. The impact of internationalization on innovation at countries' level: The role of absorptive capacity. Cambridge Journal of Economics [e-journal], (41)2, pp.413-439. doi: 10.1093/cje/bew032.

Fu, X., Pietrobelli, C. and Soete, L., 2011. The Role of Foreign Technology and Indigenous Innovation in the Emerging Economies: Technological Change and Catching-up. World Development [e-journal], 39(7), pp.1204-1212. doi: 10.1016/j.worlddev.2010.05.009.

Furman, J.L., Porter, M.E. and Stern, S., 2002. The determinants of national innovative capacity. Research Policy [e-journal], 31(6), pp.899-933. doi: 10.1016/s0048-7333(01)00152-4.

Gauselmann, A., Knell, M. and Stephan, J., 2011. What drives FDI in CentralEastern Europe? Evidence from the IWH-FDI-Micro database. Post-Communist Economies [e-journal], 23(3), pp.343-357. doi: 10.1080/14631377.2011.595148.

Ghazal, R. and Zulkhibri, M., 2015. Determinants of innovation outputs in developing countries. Journal of Economic Studies [e-journal], 42(2), pp.237260. doi: 10.1108/jes-01-2013-0016.

Gong, G. and Keller, W., 2003. Convergence and polarization in global income levels: A review of recent results on the role of international technology diffusion. Research Policy [e-journal], 32(6), pp.1055-1079. doi: 10.1016/s00487333(02)00136-1.

Gorodnichenko, Y., Svejnar, J. and Terrell, K., 2010. Globalization and Innovation in Emerging Markets. American Economic Journal: Macroeconomics [e-journal], 2(2), pp.194-226. doi: 10.1257/mac.2.2.194. 
Janoskova, K. and Kral, P., 2019. An in-depth analysis of the summary innovation index in the V4 countries. Journal of Competitiveness [e-journal], 11(2), pp.68-83. doi: 10.7441/joc.2019.02.05.

Kondratiuk-Nierodzińska, M., 2016. Innovation Capabilities In Eu Countries: Have Central And Eastern European Countries Been Catching Up? Journal of Business Economics and Management [e-journal], 17(5), pp.765-779. doi: 10.3846/16111699.2015.1114016.

Konstandina, M.S. and Gachino, G.G., 2020. International technology transfer: Evidence on foreign direct investment in Albania. Journal of Economic Studies [e-journal], 47(2), pp.286-306. doi: 10.1108/jes-02-2018-0076.

Krammer, S.M., 2009. Drivers of national innovation in transition: Evidence from a panel of Eastern European countries. Research Policy [e-journal], 38(5), pp.845-860. doi: 10.1016/j.respol.2009.01.022.

Lei, M., Zhao, X., Deng, H. and Tan, K.C., 2013. DEA analysis of FDI attractiveness for suitable development: Evidence from Chinese provinces. Decision Support Systems [e-journal], 56(1), pp.406-418. doi: 10.1016/J.DSS.2012.10.053.

Li, J., Strange, R., Ning, L.T. and Sutherland, D., 2016. Outward foreign direct investment and domestic innovation performance: Evidence from China. International Business Review [e-journal], 25(5), pp.1010-1019. doi: 10.1016/j.ibusrev.2016.01.008.

Li, Q., Lee, S. and Park, S.W., 2020. The effect of inward and outward foreign direct investment on regional innovation performance: Evidence from China. Global Business \& Finance Review [e-journal], 25(1), pp.65-88, doi: 10.17549/gbfr.2020.25.1.65.

Matusik, S.F., Heeley, M.B. and Amorós, J.E., 2019. Home court advantage? Knowledge-based FDI and spillovers in emerging economies. Global Strategy Journal [e-journal], 9(3), pp.405-422. doi: 10.1002/gsj.1324.

Ozawa, T., 1992. Theory of FDI as a dynamic paradigm of economic development. Transnational Corporations, 1(1), pp.27-54.

Pradhan, J.P. and Singh, N., 2009. Outward FDI and knowledge flows: A study of the Indian automotive sector. Institutions and Economies, 1(1), pp.156-187.

Qu, T., Chen, J., Li, S. and Xiang, H., 2013. Impact of inward FDI, import on domestic innovation: evidence from China. The International Journal of Business and Finance Research, 2013, 7(3), pp.119-136.

Ramzi, T. and Salah, A.B., 2018. The Determinants of Innovation Capacity in the Less Innovative Countries in the Euro-Mediterranean Region. Journal of the Knowledge Economy [e-journal], 9(2), pp.526-543. doi: 10.1007/s13132-0150347-3. 
Remeikiené, R., Belas, J., Kliestik, T. and Smrcka, L., 2020. Quantitative assessment of dynamics of economic development in the countries of the European Union. Technological and Economic Development of Economy [ejournal], 26(4), pp.933-946. doi: 10.3846/tede.2020.12892.

Rodríguez, C., Gómez, C. and Ferreiro, J., 2009. A proposal to improve the UNCTAD's inward FDI potential index. Transnational Corporations [e-journal], 18(3), pp.85-114. doi: 10.18356/d3e73f33-en.

Santos, G., Afonseca, J., Lopes, N., Félix, M.J. and Murmura, F., 2018. Critical success factors in the management of ideas as an essential component of innovation and business excellence. International Journal of Quality and Service Sciences [e-journal], 10(3), pp.214-232. doi: 10.1108/IJQSS-05-2017-0051.

Sarin, V. and Kumar, S., 2019. Investment abroad and impact at home: A literature review. Global Economy Journal [e-journal], 19(4), pp.419-433. doi: $10.1142 / \mathrm{S} 2194565919300011$.

Song, H. and Zhang, M., 2017. Spatial Spillovers of Regional Innovation: Evidence from Chinese Provinces. Emerging Markets Finance and Trade [ejournal], 53(9), pp.2104-2122. doi: 10.1080/1540496x.2017.1284061.

Sultana, N. and Turkina, E., 2020. Foreign direct investment, technological advancement, and absorptive capacity: A network analysis. International Business Review [e-journal], 29(2), 101668. doi: 10.1016/j.ibusrev.2020.101668.

Švandová, E. and Jirásek, M., 2019. On Measuring Countries' Innovation Performance: Organisational Level Perspective. Acta Universitatis Agriculturae Et Silviculturae Mendelianae Brunensis [e-journal], 67(3), pp.871-881. doi: 10.11118/actaun201967030871.

UNCTAD, 2002. World Investment Report: Transnational Corporations and Export Competitiveness. New York and Geneva: United Nations Publication.

UNCTAD, 2004. World Investment Report: The Shift Towards Services. New York and Geneva: United Nations Publication.

UNCTADSTAT, 2020. DataCenter. [online] Available through: <https://unctadstat.unctad.org/EN/> [Accessed 02 October 2020].

Urbančíková, N. and Zgodavová, K., 2019. Sustainability, resilience and population ageing along Schengen's eastern border. Sustainability [e-journal], 11(10), 2898. doi: 10.3390/su11102898.

Wu, J., Ma, Z. and Zhuo, S., 2017. Enhancing national innovative capacity: The impact of high-tech international trade and inward foreign direct investment. International Business Review [e-journal], 26(3), pp.502-514. doi: 10.1016/j.ibusrev.2016.11.001. 


\section{ABOUT AUTHORS}

Aneta Bobenič Hintošová - (A.B.H.) University of Economics in Bratislava, Faculty of Business Economics with seat in Košice, Košice, Slovakia, Assoc. Prof., e-mail: aneta.bobenic.hintosova@euba.sk, Author's ORCID: 0000-00018728-6328.

Michaela Bruothová - (M.B.) University of Economics in Bratislava, Faculty of Business Economics with seat in Košice, Slovakia, Assist. Prof., e-mail: michaela.bruothova@euba.sk, Author's ORCID: 0000-0002-1116-3273.

Iveta Vasková - (I.V.) Technical University of Košice, Faculty of Materials, Metallurgy and Recycling, Košice, Slovakia, Assoc. Prof., e-mail: iveta.vaskova@tuke.sk, Author's ORCID: 0000-0001-6820-4876.

\section{AUTHOR CONTRIBUTIONS}

A.B.H. - conceptualization, methodology, resources, original draft preparation; M.B. - formal analysis, data curation, review and editing, visualization; I.V. validation, review, supervision.

\section{CONFLICTS OF INTEREST}

The authors declare no conflict of interest. The funders had no role in the design of the study; in the collection, analyses, or interpretation of data; in the writing of the manuscript, or in the decision to publish the results.

(C) 2020 by the authors. Submitted for possible open access publication under the terms and conditions of the Creative Commons Attribution (CC-BY) license (http://creativecommons.org/licenses/by/4.0/). 